\title{
MARK UP MARGIN DAN IMPLIKASINYA PADA PEMBIAYAAN MURABAHAH DI BAITUL MAAL WATTAMWIL
}

\author{
Bahrul Yaman, Heri Setiawan \\ UIN Syarif Hidayatullah Jakarta \\ bahrul_yaman@yahoo.com, heri.set@gmail.com
}

\begin{abstract}
.
The purpose of this research is to analyze the influence of Third Party Fund, Non Performing Financing (NPF) and Financing Deposit to Ratio (FDR) toward Mark up margin and its implication to Murabahah Financing in BMT.. BMT study population is located in South Jakarta and Tangerang, which had stood at least 5 years and already have a good financial statements and according to standards that have been set. All sample was determined using convenience sampling, the samples were chosen based on the ease of obtaining data and not troublesome to measure and cooperative. This research used path analysis method with decomposition model. The result of substructure I indicate that Third Party Fund, Non Performing Financing (NPF) and Financing Deposit to Ratio (FDR) variabels have significantly effect to the Mark up margin. The result of substructure II indicate that Third Party Fund and Financing Deposit to Ratio (FDR) have significantly effect to the Murabahah Financing.
\end{abstract}

Keywords: Third Party Fund; NPF; FDR; Mark up Margin; Murabahah Financing

\begin{abstract}
Abstrak.
Tujuan dari penelitian ini adalah untuk menganalisis pengaruh Dana Pihak Ketiga, Non Performing Financing (NPF) dan Pembiayaan Deposit Rasio (FDR) terhadap Mark up margin dan implikasinya terhadap Murabahah di BMT. Populasi penelitian adalah BMT yang berada di wilayah Jakarta Selatan dan Tangerang, yang sudah berdiri minimal 5 tahun dan sudah memiliki laporan keuangan yang baik dan sesuai standar yang telah ditetapkan. Adapun sampel ditentukan menggunakan convenience sampling, yaitu anggota sample yang di pilih berdasarkan kemudahan memperoleh data dan tidak menyusahkan mengukurnya serta bersifat kooperatif Metode analisis jalur digunakan dalam penelitian ini dengan model dekomposisi. Hasil substruktur I menunjukkan bahwa Dana Pihak Ketiga, Non Performing Financing (NPF) dan Pembiayaan Deposit Rasio (FDR) secara signifikan mempengaruhi Mark up marjin. Hasil substruktur II menunjukkan bahwa Dana Pihak Ketiga dan Pembiayaan Deposit Rasio (FDR) secara signifikan mempengaruhi Pembiayaan Murabahah.
\end{abstract}

Kata Kunci: Dana Pihak Ketiga; NPF; FDR; Mark up Margin; Pembiayaan Murabahah 


\section{PENDAHULUAN}

Fenomena penerapan prinsip syariah dalam lembaga keuangan semakin berkembang pesat, tidak hanya di perbankan tetapi juga lembaga keuangan bukan bank (LKBB). Di sektor lembaga keuangan bank dikenal dengan perbankan syariah, sedangkan pada lembaga keuangan bukan bank dengan mengacu pada Penjelasan Pasal 49 huruf $\mathrm{i}$ Undang Undang Nomor 3 Tahun 2006 tentang Perubahan Atas Undang-undang Nomor 7 Tahun 1989 tentang Peradilan Agama, terdiri dari lembaga keuangan mikro syariah, asuransi syariah, reasuransi syariah, reksadana syariah, obligasi syariah dan surat berharga berjangka menengah syariah, sekuritas syariah, pembiayaan syariah, pegadaian syariah, dana pensiun lembaga keuangan syariah, dan bisnis syariah. (Suhendi, 2008).

Penawaran kredit perbankan ternyata tidak hanya dipengaruhi oleh Dana Pihak Ketiga (DPK), Menurut Warjiyo (2004), dalam kenyataannya perilaku penawaran kredit perbankan tidak hanya di pengaruhi oleh dana yang tersedia yang bersumber dari Dana Pihak Ketiga (DPK), tetapi juga dipengaruhi oleh persepsi bank terhadap prospek usaha debitor dan kondisi perbankan itu sendiri seperti permodalan atau Capital Adequacy Ratio (CAR), jumlah kredit macet atau Non Performing Loans (NPL), dan Loan to Deposit Ratio (LDR). Sutaji (2007), menyebutkan faktor Suku Bunga Kredit dan Inflasi berpengaruh negatif dalam penyaluran dana Kredit pada Bank Umum.

Kemampuan BMT untuk memberikan pembiayaan kepada usaha kecil tidak mungkin di gantikan oleh bank syariah. Bank syariah tidak mungkin beroperasi dalam pembiayaan skala kecil, sementara masyarakat membutuhkan permodalan kecil tersebut. Sehingga kehadiran BMT merupakan suatu kebutuhan dalam membangun hubungan vertikal dengan bank syariah maupun pemenuhan kebutuhan masyarakat. (Aries Muftie : 2006).

Krisis moneter yang melanda bangsa Indonesia pada 2008-2009 awal yang lalu menyebabkan sektor riil, hampir lumpuh dengan banyaknya pengusaha yang 'gulung tikar' alias mengalami kebangkrutan. Dalam realitasnya, operasional bank syariah belum dapat secara optimal menjangkau sektor usaha mikro di tingkat akar rumput (grass root). Hal demikian karena ternyata bank syariah sebagai lembaga intermediasi keuangan dalam menjalankan fungsinya menyalurkan dana kepada masyarakat berupa memberikan pembiayaan masih mensyaratkan adanya jaminan yang itu tidak 
mudah bisa dipenuhi oleh nasabah, khususnya nasabah kecil. Di sisi yang lain fakta menunjukkan bahwa operasional bank syariah juga terbatas di kota-kota, sedangkan pelaku sektor ekonomi riil juga sebagian diberikan oleh bank syariah belum dapat menjangkau sektor ekonomi riil secara optimal. (Hendi Suhendi, 2008).

Kondisi tersebut menjadi latar belakang munculnya lembaga lembaga keuangan mikro yang sudah menjangkau hingga ke pedesaan-pedesaan atau yang dikenal dengan sebutan BMT. BMT dalam operasional usahanya pada dasarnya hampir mirip dengan perbankan yaitu melakukan kegiatan penghimpunan dana dari masyarakat dalam bentuk simpanan dan menyalurkan dana kepada masyarakat yang membutuhkan dalam bentuk pembiayaan, serta memberikan jasa-jasa yang dibutuhkan oleh masyarakat.

Dalam transaksi murabahah bank-bank Islam tidak turut menanggung untung dan rugi, melainkan lebih banyak menerima peran intermediasi finansial klasik. Dalam murabahah tradisional, menurut kitab-kitab fikih (yurispudensi), mark-up berbeda dengan bunga karena mark-up tidak harus secara eksplisit dihubungkan dengan tempo pinjaman melainkan dihitung berdasarkan transaksi untuk layanan yang diberikan dan bukan untuk pembayaran yang ditangguhkan (deferred payment). Pembayaran ini biasa dilakukan dengan menggunakan letter of credit (LC) yang memohon kepada bank untuk membeli/mengimpor barang tertentu. Bank akan mengeluarkan LC dan membayarkan hasilnya kepada bank yang melaksanakan negosiasi. Bank menjual barang yang dipesan kepada konsumen begitu barangnya tiba. (Antonio, 2001).

Baitul Mal wat-Tamwil diperlukan masyarakat dengan pertimbangan-pertimbangan: pertama, masih terdapat kurang lebih 34,8 juta pengusaha kecil di Indonesia. Kedua, masih sangat sedikit lembaga perbankan yang mampu berhubungan langsung dengan pengusaha kecil bawah dan kecil. Kalaupun ada lembaga-lembaga keuangan yang dapat berhubungan langsung dengan pengusaha kecil bawah dan kecil bersifat profit oriented sehingga ada kecenderungan mereka selalu menjadi pihak yang dirugikan. (Kholis, 2007).

Menganalisis dari kurangnya kemampuan bank syariah menyentuh golongan bawah yang justru sangat membutuhkan modal dengan syarat yang mudah dan pengembalian yang tidak memberatkan, BMT ini perlu dikembangkan. Terutama dalam 
hal pembiayaan kepada usaha-usaha kecil, penulis mencoba menganlisis pengaruh DPK, NPF, FDR dan Markup margin terhadap Pembiayaan Murabahah pada BMT.

Adapun tujuan penelitian ini adalah (1). Menganalisis pengaruh DPK, NPF dan FDR terhadap Mark up margin pada BMT, (2) Menganalisis pengaruh DPK, NPF, FDR dan Mark up margin terhadap pembiayaan Murabahah pada BMT, (3) Menganalisis pengaruh total (hubungan langsung dan tidak langsung DPK, NPF, FDR dan Mark up margin terhadap pembiayaan Murabahah pada BMT.

Pratin dan Adnan (2005) meneliti tentang simpanan modal sendiri, NPL, prosentasi bagi hasil dan mark up keuntungan terhadap pembiayaan Perbankan Syariah pada Bank Muamalat Indonesia. Tujuan penelitian ini adalah untuk mengetahui sejauh mana hubungan simpanan, modal sendiri, NPL, prosentase bagi hasil dan markup keuntungan terhadap besarnya pembiayaan pada perbankan syariah. Perhitungan dan interpretasi dari analisis data dilakukan dengan bantuan program aplikasi komputer. Pengujian hipotesis menggunakan metode analisis uji-t. Kesimpulan yang dapat diambil dari hasil penelitian ini adalah simpanan mempunyai hubungan positif dan signifikan terhadap pembiayaan, sementara variabel yang lain tidak mempunyai hubungan yang signifikan.

Heykal (2007) meneliti tentang faktor-faktor yang mempengaruhi penetapan margin murabahah untuk produk pembiayaan pemilikan rumah pada PT Bank Syariah Mandiri. Penelitian ini bertujuan untuk mengetahui faktor yang mempengaruhi penetapan margin murabahah tersebut, sehingga banyak terdengar keluhan bahwa pembiayaan rumah dari bank syariah jauh lebih tinggi dan memberatkan dibandingkan dengan perbankan konvensional. Hasil penelitian ini adalah: (1). Biaya Overhead cukup besar dalam mempengaruhi margin murabahah pembiayaan pemilikan rumah, dan di buktikan dengan tingkat signifikansi sebesar 0,004. (2). Proporsi beban bagi hasil DPK terhadap margin murabahah kepemilikan rumah juga cukup besar, dan dibuktikan dengan tingkat signifikansi sebesar 0,001. (3). Tingkat keuntungan yang diinginkan oleh bank tidak mempengaruhi tingkat margin murabahah untuk kepemilikan rumah. (4). Tingkat bunga pinjaman bank konvensional berpengaruh sangat besar terhadap margin murabahah untuk kepemilikan rumah, dengan tingkat signifikansi sebesar 0,000 . 
Bardaini (2006) meneliti tentang hubungan kredit usaha Baitul Maal Wattamwil (BMT) dengan pendapatan usaha mikro di kabupaten Tegal. Penelitian ini bertujuan untuk mengetahui ada tidaknya hubungan antara kredit usaha Baitul Maal Wattamwil (BMT) dengan pendapatan usaha mikro di Kabupaten Tegal. Hasil penelitian menunjukkan bahwa data kredit usaha Baitul Maal Wattamwil (BMT) di Kabupaten Tegal skor yang diperoleh sebesar 7.852 dibandingkan dengan skor maksimum 11.640 atau sebesar $67.46 \%$. Sedangkan data pendapatan usaha mikro di Kabupaten Tegal diperoleh sebesar 4.114 dibandingkan dengan skor maksimum 5.820 atau sebesar $70.69 \%$.

Hasil pengolahan data diketahui nilai korelasi atau $r$ sebesar $74.5 \%$ sedangkan nilai $t$ tabel kritis Product Moment pada interval kepercayaan 95\% N = 97 sebesar 19.5\%. Dengan demikian hipotesis nol $\left(\mathrm{H}_{0}\right)$ dalam penelitian ini dinyatakan ditolak dan hipotesis alternatif $(\mathrm{Ha})$ diterima, yang artinya ada hubungan kredit usaha Baitul Maal Wattamwil (BMT) dengan pendapatan usaha mikro di Kabupaten Tegal. Sumbangan efektif variabel bebas terhadap variabel terikat sebesar 0.555 atau $55.5 \%$, sedangkan sisanya sebesar $44.5 \%$ dipengaruhi oleh variabel lain yang tidak diungkap dalam penelitian ini. Berdasarkan hasil penelitian tersebut dapat disimpulkan bahwa ada hubungan kredit usaha BMT dengan pendapatan usaha mikro di Kabupaten Tegal, data kredit usaha BMT di Kabupaten Tegal rata-rata termasuk dalam kriteria baik dan data pendapatan usaha mikro di Kabupaten Tegal termasuk dalam kriteria baik.

Hasil penelitian ini diharapkan dapat menjadi bahan pertimbangan pengurus BMT di dalam mendesain sistem kredit yang baik dalam pengelolaan usaha BMT, sehingga dapat meningkatkan mutu kinerja BMT dan pengusaha mikro di Kabupaten Tegal dalam meningkatkan kesejahteraan BMT dan pengusaha mikro. Salah satu cara yaitu meningkatkan kinerja manajemen yang profesional dan dibentuk program pembinaan usaha mikro yang profesional.

Abdul Rosyid (2009), meneliti tentang pengaruh DPK, CAR, NPL, LDR dan Inflasi terhadap Penawaran Kredit Investasi Pada Bank Persero. Penelitian ini bertujuan untuk mengetahui pengaruh Dana Pihak Ketiga (DPK), Capital Adequacy Ratio (CAR), Non Performing Loan NPL), Loan to Deposit Ratio (LDR) dan Inflasi terhadap Kredit Investasi pada Bank Persero. Data yang digunakan dalam penelitian ini berupa data Sekunder yang dikumpulkan dari hasil publikasi Bank Indonesia 
pada statistik perbankan dan studi literatur lain. Metode pengolahan data menggunakan metode analisis jalur. Pengujian statistik dalam penelitian ini menggunakan Uji t dan F. Hasil penelitian ini dapat diketahui bahwa variabel DPK, CAR, NPL, LDR dan Inflasi berpengaruh signifikan pada Penawaran Kredit Investasi pada Bank Persero. Dalam penelitian ini diketahui bahwa variabel DPK, CAR, NPL, LDR dan Inflasi berpengaruh total terhadap Penawaran Kredit Investasi sebesar 0,939 .

\section{METODE}

Penelitian ini dilakukan pada BMT yang berada di wilayah Jakarta Selatan dan Tangerang dengan melihat laporan keuangan BMT tersebut dari periode 2006-2009. Pengumpulan data dilakukan, baik melalui observasi terhadap dokumen atau laporan instansi terkait maupun hasil publikasi, kemudian dilakukan pencatatan terhadap data yang dibutuhkan.

Populasi penelitian adalah BMT yang berada di wilayah Jakarta Selatan dan Tangerang, yang sudah berdiri minimal 5 tahun dan sudah memiliki laporan keuangan yang baik dan sesuai standar yang telah ditetapkan. Adapun sampel ditentukan menggunakan convenience sampling, yaitu anggota sampel yang dipilih berdasarkan kemudahan memperoleh data dan tidak menyusahkan mengukurnya serta bersifat kooperatif.

Analisis jalur merupakan pengembangan dari model regresi yang digunakan untuk kesesuaian (fit) dari matrik korelasi dari dua atau lebih model yang dibandingkan oleh si peneliti. Model biasanya digambarkan dengan lingkaran dan anak panah yang menunjukkan hubungan kausalitas. Regresi dilakukan untuk setiap variabel dalam model. Nilai regresi yang diprediksi oleh model dibandingkan dengan matrik korelasi hasil observasi variabel dan nilai goodness of-fit di hitung. Model terbaik dipilih berdasarkan nilai goodness of fit (Ghozali, 2008). 


\section{HASIL DAN PEMBAHASAN}

\section{Analisis Jalur Pengaruh Dana Pihak ketiga (DPK), Non Performing Financing (NPF) dan Financing to Deposite Ratio (FDR) terhadap Mark up margin dan implikasinya pada Pembiayaan Murabahah BMT.}

Analisis jalur ini dibagi menjadi dua substruktur. Substruktur yang pertama menganalisis pengaruh Dana Pihak ketiga (DPK), Non Performing Financing (NPF) dan Financing to Deposite Ratio (FDR) sebagai variabel eksogen terhadap Mark up margin sebagai variabel endogen. Substruktur kedua menganalisis Dana Pihak ketiga (DPK), Non Performing Financing (NPF), Financing to Deposite Ratio (FDR) dan Mark up margin sebagai variabel eksogen pada Pembiayaan murabahah sebagai variabel endogen.

Berdasarkan perhitungan, diperoleh angka korelasi antara variabel Dana Pihak Ketiga (DPK) dan Financing to Deposite Ratio (FDR) sebesar -0,131. Korelasi sebesar -0,131 mempunyai maksud hubungan antara variabel Dana Pihak Ketiga (DPK) dan Financing to Deposite Ratio (FDR) sangat lemah dan berlawanan artinya apabila terjadi kenaikan Dana Pihak Ketiga (DPK), maka nilai dari FDR akan mengalami penurunan. Korelasi dua variabel tersebut mempunyai probabilitas sebesar 0,272 > 0,05 maka dapat di simpulkan tidak terdapat hubungan yang signifikan antara variabel tersebut.

Korelasi antara Financing to Deposite Ratio (FDR) dan Non $\square$ Performing Financing (NPF). $\square$ Berdasarkan perhitungan, diperoleh angka korelasi 0,371 antara variabel mempunyai maksud hubungan antara variabel Financing to Deposite Ratio (FDR) dan Non Performing Financing (NPF) sangat kuat dan searah artinya apabila terjadi kenaikan FDR $\square$ maka nilai dari NPF akan mengalami kenaikan, dan sebaliknya. Korelasi dua variabel tersebut mempunyai probabilitas sebesar $0,003>0,05$ maka disimpulkan terdapat hubungan yang signifikan antara variabel tersebut.

Korelasi antara Dana Pihak Ketiga (DPK) dan Non Performing Financing (NPF) Berdasarkan perhitungan, diperoleh angka korelasi antara variabel DPK dan NPF sebesar 0,543. Korelasi sebesar 0,543 mempunyai maksud hubungan antara variabel DPK dan NPF sangat kuat dan searah. Searah artinya apabila terjadi kenaikan DPK, maka nilai dari NPF akan mengalami kenaikan, dan sebaliknya. Korelasi dua variabel 
tersebut mempunyai probabilitas sebesar 0,000 $>0,05$ maka terdapat hubungan yang signifikan antara variabel tersebut.

Analisis Jalur Pengaruh Dana Pihak Ketiga (DPK), Non Performing Financing (NPF) dan Financing to Deposite Ratio (FDR) terhadap Mark up margin.

Hasil uji ditemukan bahwa angka $R$ square adalah 0,888 . Hal ini berarti kemampuan variabel independen menjelaskan atau pun mempengaruhi variabel dependen sebesar 88,8 persen. Sedangkan sisanya sebesar $11,2 \%(100 \% 88,8 \%)$ dipengaruhi oleh faktor lain:

\section{Pengaruh antara variabel Dana Pihak Ketiga (DPK) dengan Mark up margin}

Hasil uji menunjukkan bahwa variabel DPK berpengaruh signifikan terhadap Mark up margin. Besarnya pengaruh Dana Pihak Ketiga (DPK) terhadap Mark up margin sebesar -0,208 atau -208\%. Dana Pihak Ketiga (DPK) memiliki pengaruh yang negatif dan signifikan terhadap Mark up margin. Artinya, apabila terjadi kenaikan Dana Pihak Ketiga (DPK), maka tingkat Mark up margin akan mengalami penurunan, begitu juga sebaliknya. Hal ini sesuai dengan penelitian yang dilakukan oleh Mohamad Heykal, (2007) bahwa dana pihak ketiga secara parsial memiliki pengaruh secara signifikan terhadap penetapan Mark up margin murabahah untuk pembiayaan kepemilikan rumah pada Bank Syariah Mandiri.

\section{Pengaruh antara variabel Non Performing Financing (NPF) dengan Mark up margin}

Hasil uji menunjukkan bahwa variabel NPF berpengaruh signifikan terhadap Mark up margin. Besarnya pengaruh Non Performing Financing (NPF) terhadap Mark up margin sebesar - 0,560 atau -560\%. Non Performing Financing (NPF) memiliki pengaruh yang negatif dan signifikan terhadap Mark up margin. Artinya, apabila terjadi kenaikan Non Performing Financing (NPF), maka tingkat Mark up margin akan mengalami penurunan, begitu juga sebaliknya.

\section{Pengaruh antara variabel Financing to Deposite Ratio (FDR) dengan Mark up margin}

Hasil uji menunjukkan bahwa variabel FDR berpengaruh signifikan terhadap Mark up margin. Besarnya pengaruh Financing to Deposite Ratio (FDR) terhadap Mark up margin sebesar $-0,408$ atau $-408 \%$. Financing to Deposite Ratio (FDR) memiliki pengaruh yang negatif dan signifikan terhadap Mark up margin. Artinya, apabila terjadi 
kenaikan Financing $t$ Mark up margin akan mengalami penurunan, begitu juga sebaliknya.

Analisis Jalur Pengaruh Variabel Dana Pihak Ketiga (DPK), Non Performing Financing (NPF), Financing to Deposit Ratio (FDR) dan Mark up margin Pada Pembiayaan Murabahah BMT.

Untuk melihat pengaruh variabel Dana Pihak Ketiga (DPK), Non Performing Financing (NPF), Financing to Deposit Ratio (FDR) dan Mark up margin Pada Pembiayaan Murabahah secara gabungan dapat dilihat besarnya angka $R$ square (R2) adalah sebesar 0,985 . Sedangkan sisanya sebesar $1,5 \%$ dipengaruhi oleh faktor lain. Dengan kata lain, variabilitas kepuasan yang dapat diterangkan dengan menggunakan variabel DPK, NPF, FDR dan Mark up margin Pada Pembiayaan Murabahah sebesar 98,5\%, sementara pengaruh $1,5 \%$ disebabkan oleh variabel-variabel lain di luar model ini. Rangkuman seluruh pengujian pengaruh antar variabel eksogen dan endogen dapat dijelaskan sebagai berikut:

\section{Pengaruh antara variabel Dana Pihak Ketiga (DPK) dengan Pembiayaan Murabahah.}

Besarnya pengaruh Dana Pihak Ketiga (DPK) pada Pembiayaan Murabahah sebesar 0,955 atau 95,5\%. Dana Pihak Ketiga (DPK) memiliki pengaruh yang positif dan signifikan terhadap Pembiayaan. Artinya, apabila terjadi kenaikan Dana Pihak Ketiga (DPK), maka jumlah Pembiayaan juga akan mengalami kenaikan, begitu juga sebaliknya. Hal ini sesuai dengan penelitian yang dilakukan oleh Adnan (2005) bahwa dana pihak ketiga secara parsial memiliki pengaruh terhadap jumlah pembiayaan yang disalurkan.

Pengaruh antara variabel Non Performing Financing (NPF), dengan Pembiayaan Murabahah.

Hasil uji ditemukan bahwa tidak ada hubungan linier antara variabel Non Performing Financing (NPF) dengan Pembiayaan Murabahah. Besarnya pengaruh Non Performing Financing (NPF) pada Pembiayaan Murabahah sebesar 0,016 atau 1,6\%. Hal ini sesuai dengan penelitian yang dilakukan oleh Adnan (2005) bahwa variabel NPF mempunyai tidak memiliki hubungan positif yang signifikan terhadap pembiayaan. Hubungan yang tidak signifikan ini antara lain disebabkan karena permintaan pembiayaan yang cukup tinggi di bank syariah, kekhususan dalam penanganan 
pembiayaan yang bermasalah dibanding dengan bank konvensional dan kecilnya peluang moral hazard pada bank syariah.

Pengaruh antara variabel Financing to Deposit Ratio (FDR), dengan Pembiayaan Murabahah.

Hasil uji ditemukan ada hubungan linier antara variabel Financing Deposit to Ratio (FDR) dengan Pembiayaan Murabahah. Besarnya pengaruh Financing to Deposit Ratio (FDR) pada Pembiayaan Murabahah sebesar 0,315 atau 31,5\%. Hal ini sesuai dengan penelitian Rosyid (2009), bahwa LDR mempengaruhi penawaran kredit pada bank.

\section{Pengaruh antara variabel Mark up margin dengan Pembiayaan Murabahah.}

Hasil uji ditemukan tidak ada hubungan linier antara variabel Mark up margin dengan Pembiayaan Murabahah. Besarnya pengaruh Mark up margin pada Pembiayaan Murabahah sebesar $-0,022$ atau $-2,2 \%$. Hal ini sesuai dengan penelitian yang dilakukan oleh Pratin dan Adnan (2005) bahwa secara parsial Mark up margin mempunyai hubungan negatif tidak signifikan. Selain itu menurut peneliti ada beberapa faktor yang mempengaruhinya antara lain: Faktor emosi keagamaan lebih berperan dalam penentuan nasabah mengajukan pembiayaan kepada BMT, sehingga tidak terlalu menghiraukan besarnya Markup yang ditetapkan Permintaan Pembiayaan Murabahah yang cukup tinggi di BMT.

\section{Analisis Jalur Setelah Trimming}

Korelasi antara Dana Pihak Ketiga (DPK), Non Performing Financing (NPF), Financing to Deposite Ratio (FDR) tidak berbeda dengan analisis korelasi sebelum trimming.

Analisis Jalur Pengaruh Dana Pihak Ketiga (DPK), Non Performing Financing (NPF), Financing to Deposite Ratio (FDR) pada Mark up margin Secara Simultan dan Parsial.

Besarnya pengaruh variabel Dana Pihak Ketiga (DPK), Non Performing Financing (NPF), Financing to Deposite Ratio (FDR) pada Mark up margin secara simultan adalah $88,8 \%$, sedangkan sisanya sebesar $11,2 \%$ dipengaruhi oleh faktor lain. Besarnya pengaruh Dana Pihak Ketiga (DPK) terhadap Mark up margin sebesar 0,298 atau $-29,8 \%$, pengaruh NPF terhadap Mark up margin sebesar $-0,560$ atau $-56 \%$ dan pengaruh Inflasi terhadap Pembiayaan sebesar $-0,408$ atau $-40,8 \%$. 
Analisis Jalur Pengaruh DPK, NPF, FDR dan Mark up margin Pada Pembiayaan Murabahah Secara Simultan dan Parsial

Besarnya pengaruh variabel DPK, NPF, FDR dan Mark up margin Pada Pembiayaan Murabahah secara simultan adalah 98,4\%, sedangkan sisanya sebesar 1,6\% dipengaruhi oleh faktor lain. Besarnya pengaruh Dana Pihak Ketiga (DPK) pada Pembiayaan sebesar 0,979 atau 97,9\% dan pengaruh Financing to Deposit Ratio (FDR) pada Pembiayaan Murabahah sebesar 0,337 atau $33,7 \%$.

\section{Pengaruh antara variabel Dana Pihak Ketiga (DPK) dengan Pembiayaan Murabahah}

Hasil perhitungan menunjukkan angka $0,000<0,05$. Maka telah cukup data untuk menolak $\mathrm{HO}$ dan menerima Ha. Artinya, ada hubungan linier antara variabel Dana Pihak Ketiga (DPK) dengan Pembiayaan Murabahah Besarnya pengaruh Dana Pihak Ketiga (DPK) pada Pembiayaan Murabahah sebesar 0,979 atau 97,9\%. Dana Pihak Ketiga (DPK) memiliki pengaruh yang positif dan signifikan terhadap Pembiayaan, artinya, apabila terjadi kenaikan Dana Pihak Ketiga (DPK), maka jumlah Pembiayaan juga akan mengalami kenaikan, begitu juga sebaliknya. Hal ini sesuai dengan penelitian yang dilakukan oleh Pratin dan Adnan (2005) bahwa dana pihak ketiga secara parsial memiliki pengaruh terhadap jumlah pembiayaan yang disalurkan.

Pengaruh antara variabel Financing to Deposit Ratio (FDR), dengan Pembiayaan Murabahah.

Hasil perhitungan menunjukkan angka $0,000<0,05$. Maka telah cukup data untuk menolak Ho dan menerima Ha. Artinya, ada hubungan linier antara variabel Financing Deposit Ratio (FDR) dengan Pembiayaan Murabahah. Besarnya pengaruh Financing to Deposit Ratio (FDR) pada Pembiayaan Murabahah sebesar 0,337 atau 33,7\%. Hal ini sesuai dengan penelitian Rosyid (2009), bahwa LDR mempengaruhi penawaran kredit pada bank.

\section{Hubungan Langsung dan Tidak Langsung}

Beberapa pengaruh langsung dan tidak langsung (melalui Mark up margin dan Pembiayaan, serta melaui Pembiayaan dan Mark up margin) dan pengaruh total tentang pengaruh Dana Pihak Ketiga (DPK), Non Performing Finance (NPF), Financing 
to Deposit Ratio (FDR) dan Mark up margin pada pembiayaan dapat dilihat pada tabel dan uraian sebagai berikut:

1. Pengaruh antara variabel Dana Pihak Ketiga (DPK) terhadap Mark up margin. Dana Pihak Ketiga (DPK) memiliki pengaruh langsung/pengaruh total terhadap Mark up Margin sebesar -0,298.

2. Pengaruh antara variabel Non Performing Finance (NPF) terhadap Mark up margin Non Performing Finance (NPF) memiliki pengaruh langsung pengaruh total) terhadap mark up margin sebesar -0.560

3. Pengaruh antara variabel Financing to Deposit Ratio (FDR) terhadap Mark up Margin Financing to Deposit Ratio (FDR) memiliki pengaruh langsung pengaruh total) terhadap Mark up Margin sebesar -0.408

4. Pengaruh antara variabel Dana Pihak Ketiga (DPK) terhadap Pembiayaan Murabahah BMT. Dana Pihak Ketiga (DPK) memiliki pengaruh langsung/pengaruh total terhadap Pembiayaan Murabahah BMT sebesar 0.979 .

5. Pengaruh antara variabel Financing to Deposit Ratio (FDR) terhadap Pembiayaan Murabahah BMT Financing to Deposit Ratio (FDR) memiliki pengaruh langsung pengaruh total) terhadap Pembiayaan Murabahah BMT sebesar 0.337 .

Berdasarkan uraian tersebut maka dapat disusun persamaan path analysis setelah trimming sebagai berikut :

\section{Persamaan Sub Struktur I}

\section{Mark up $=-0.298$ DPK + -0.560 NPF + -0.408 FDR + 0,112 $1 ;$ Rsquare $=0,888$}

Hasil pengujian setelah trimming secara simultan, diketahui variabel DPK, NPF dan FDR margin yang ditetapkan oleh BMT. Hasil pengujian secara parsial, diketahui variabel DPK, NPF dan FDR memiliki pengaruh negatif signifikan terhadap Mark up margin yang ditetapkan oleh BMT, artinya apabila jumlah DPK, NPF dan FDR meningkat, maka tingkat Mark up margin yang ditetapkan akan menurun dan sebaliknya. Hal ini sesuai dengan penelitian yang dilakukan oleh Heykal, (2007) bahwa Dana Pihak Ketiga secara parsial memiliki pengaruh secara signifikan terhadap penetapan Mark up margin murabahah untuk pembiayaan kepemilikan rumah pada Bank Syariah Mandiri. 


\section{Persamaan Sub Struktur II}

\section{Pembiayaan Murabahah $=0.979$ DPK + 0.337 FDR + 0,16 $1 ;$ Rsquare = 0,984}

Hasil pengujian setelah trimming secara simultan, diketahui variabel Dana Pihak Ketiga (DPK) dan Financing Deposit Ratio (FDR) berpengaruh signifikan pada Pembiayaan. Hasil pengujian secara parsial, diketahui bahwa variabel Dana Pihak Ketiga (DPK) dan Financing to Deposit Ratio (FDR) memiliki pengaruh yang positif dan signifikan pada Pembiayaan Murabahah pada BMT. Dana Pihak Ketiga (DPK) memiliki pengaruh yang positif dan signifikan pada Pembiayaan Murabahah. Artinya apabila terjadi kenaikan Dana Pihak Ketiga (DPK), maka Pembiayaan Murabahah pada BMT juga akan mengalami kenaikan, begitu juga sebaliknya. Hal ini sesuai dengan penelitian yang dilakukan oleh Pratin dan Adnan (2005) bahwa dana pihak ketiga secara parsial mempunyai hubungan yang positif dan signifikan terhadap Pembiayaan yang disalurkan. Luh Gede Meydianawathi (2007), secara serempak variabel DPK, ROA, CAR dan NPL berpengaruh nyata dan signifikan terhadap penawaran kredit perbankan kepada sektor UMKM. Ketiga, secara parsial variabel DPK, ROA dan CAR berpengaruh positif dan signifikan terhadap penawaran kredit bank umum. Hasil ini juga didukung oleh pendapat yang dikemukakan oleh Wibowo (2007) dan Amiranti (2009) yang secara rinci berpendapat bahwa jika dana pihak ketiga meningkat maka jumlah dana yang dapat disalurkan kepada masyarakat juga bertambah. Financing to Deposit Ratio (FDR), memiliki pengaruh yang positif dan signifikan pada Pembiayaan Murabahah yang disalurkan, artinya apabila terjadi kenaikan FDR, maka Pembiayaan Murabahah yang disalurkan juga akan mengalami kenaikan. Hal ini sesuai dengan penelitian yang dilakukan Norman (2009) yang meneliti tentang faktor-faktor yang mempengaruhi likuiditas bank syariah bahwa Pembiayaan memiliki pengaruh positif dan signifikan. Warjiyo (2004), dalam kenyataannya perilaku penawaran kredit perbankan tidak hanya dipengaruhi oleh dana yang tersedia yang bersumber dari DPK (Dana Pihak Ketiga), tetapi juga dipengaruhi oleh persepsi bank terhadap prospek usaha debitor dan kondisi perbankan itu sendiri seperti permodalan atau CAR (Capital Adequacy Ratio), jumlah kredit macet atau NPLs (Non Performing Loans), dan LDR (Loan to Deposit Ratio).

\section{SIMPULAN}

Berdasarkan hasil pembahasan yang telah dilakukan, maka dapat diambil kesimpulan bahwa hasil pengujian sebelum dan setelah trimming, diketahui bahwa variabel Dana Pihak Ketiga (DPK), Non Performing Financing (NPF) dan Financing to Deposit Ratio 
(FDR) memiliki pengaruh secara simultan terhadap tingkat Mark up margin yang ditetapkan oleh BMT sebesar 0,888. Hasil pengujian secara parsial, diketahui bahwa Dana Pihak Ketiga (DPK), Non Performing Financing (NPF) dan Financing to Deposit Ratio (FDR) memiliki pengaruh negatif signifikan terhadap Mark up margin yang ditetapkan oleh kedua BMT.

Hasil pengujian sebelum trimming, diketahui bahwa variabel Dana Pihak Ketiga (DPK), Non Performing Financing (NPF) dan Financing Deposit to Ratio (FDR) Mark up margin yang ditetapkan oleh BMT memiliki pengaruh secara simultan pada Pembiayaan Murabahah BMT sebesar 0,985. Hasil pengujian secara parsial, diketahui bahwa hanya variabel Dana Pihak Ketiga (DPK) dan Financing to Deposit Ratio (FDR) yang berpengaruh signifikan pada Pembiayaan Murabahah BMT. Hasil pengujian setelah trimming secara simultan, diketahui bahwa Dana Pihak Ketiga (DPK) dan Financing to Deposit Ratio (FDR) memiliki pengaruh secara simultan pada Pembiayaan Murabahah BMT AL-FATH \& UBASYADA sebesar 0,984. Hasil pengujian secara parsial menunjukkan bahwa Dana Pihak Ketiga (DPK) dan Financing to Deposit Ratio (FDR) memiliki pengaruh yang positif dan signifikan pada Pembiayaan Murabahah di BMT AL-FATH \& UBASYADA.

Pengaruh total (Hubungan langsung dan tidak langsung) antar variabel. Beberapa pengaruh langsung dan tidak langsung (melalui Mark up margin dan Pembiayaan, serta melaui Pembiayaan dan Mark up margin) dan pengaruh total tentang pengaruh Dana Pihak Ketiga (DPK), Non Performing Finance (NPF), Financing to Deposit Ratio (FDR) dan Mark up margin pada pembiayaan dapat dilihat pada tabel dan uraian, yaitu: Pengaruh antara variabel Dana Pihak Ketiga (DPK) terhadap Mark up margin. Dana Pihak Ketiga (DPK) memiliki pengaruh langsung/pengaruh total terhadap Mark up Margin sebesar -0,298.

Pengaruh antara variabel Non Performing Finance (NPF) terhadap Mark up margin Non Performing Finance (NPF) memiliki pengaruh langsung pengaruh total) terhadap mark up margin sebesar -0.560. Pengaruh antara variabel Financing to Deposit Ratio (FDR) terhadap Mark up Margin Financing to Deposit Ratio (FDR) memiliki pengaruh langsung pengaruh total) terhadap Mark up Margin sebesar -0.408. Pengaruh antara variabel Dana Pihak Ketiga (DPK) terhadap Pembiayaan Murabahah BMT. Dana Pihak Ketiga (DPK) memiliki pengaruh langsung/pengaruh total terhadap Pembiayaan Murabahah BMT sebesar 0.979. Pengaruh antara variabel Financing to Deposit Ratio 
(FDR) terhadap Pembiayaan Murabahah BMT Financing to Deposit Ratio (FDR) memiliki pengaruh langsung pengaruh total) terhadap Pembiayaan Murabahah BMT sebesar 0.337.

\section{PUSTAKA ACUAN}

Amin, Riawan. 2009. Menata Perbankan Syariah di Indonesia. Jakarta : UIN Press.

Antonio, Syafi'i. 2001. Bank syariah dari teori ke praktek. Jakarta : Gema Insani Press.

Arifin, Zainul. 2006. Dasar-Dasar Manajemen Bank Syaria. cetakan 4, Jakarta : Pustaka Alvabet.

Azis, Amin. 2006. Tata Cara Pendirian BMT. Cetakan 1, Jakarta : PKES.

Djumhana, Muhammad. 1996. Hukum Perbankan di Indonesia. Jakarta : PT. Citra Aditya.

Frederic S. Mishkin. 2008. Ekonomi Uang, Perbankan, dan Pasar Keuangan. Jakarta: Salemba Empat.

Ghozali, Imam. 2008. Model Persamaan Struktural Konsep dan Aplikasi Dengan Program Amos 16.0. Semarang : Badan Penerbit UNDIP.

Hakim, Lukman dan Muhammad Sholahuddin. 2008. Lembaga Ekonomi dan Keuangan Syariah Kontemporer. Surakarta : Muhammadiyah University Press.

Karim, Adiwarman. 2004. Bank Islam: Analisis Fikih dan Keuangan. Jakarta : PT Raja Grafindo Persada.

Kholis, Nur, 2007. Ringkasan Riset Kajian Kepatuhan Syariah Dalam Praktik Pembiayaan di BMT Sleman, Yogyakarta. Jurnal Penelitian \& Pengabdian

Levin, Richard I and David S Rubin. 1998. Statistic For Management. USA : Prentice Hall.

Amin, Ma'ruf. 2007. Prospek Cerah Perbankan Islam. Jakarta: LeKAS.

Martokoesoemo, Soeksmono Besar. 1995. Di Luar Batas Sektor Perbankan dan Keuangan Formal Indonesia (Perantaraan keuangan untuk Memobilisasi Potensi Wiraswatawan kecil).jakarta : Institut Bankir Indonesia.

Meydianawathi, Luh Gede. 2007. Analisis Perilaku Penawaran Kredit Perbankan Kepada Sektor UMKM di Indonesia. Buletin Studi Ekonomi Volume 12 Nomor 2 Tahun 2007.

Muhammad. 2004. Etika Bisnis Islam. Yogyakarta : Penerbit: UPP AMP YKPN.

Muhammad. 2005. Manajemen Pembiayaan Bank Syari'ah. Yogyakarta : AMP YKPN. 
Norman, Ali. 2005. Judul (Tesis Tidak Dipublikasikan). Jakarta : Universitas Indonesia.

Perwataatnadja, Karnaen dan Tanjung, Hendri, 2006. Bank Syariah, teori, praktik dan pernannya. Jakarta : Celestial Publishing.

Pratin dan M. Akhyar Adnan. 2005. Analisis Hubungan Simpanan, Modal Sendiri, NPL, Prosentase Bagi Hasil dan Mark up Keuntungan terhadap Pembiayaan pada Perbankan Syariah Studi Kasus pada Bank Muamalat Indonesia (BMI). SINERGI Edisi Khusus on Finance.

Rivai, Veithzal. 2007. Bank and Financial Institution Management Conventional \& Syaria System. Jakarta : PT. Raja Grafindo Persada.

Riyadi, Slamet. 2004. Banking Assets And Liability Management. Jakarta: Fakultas Ekonomi Universitas Indonesia.

Rose, Peter S. dan James W. 1995. Financial Institution: Understanding and Managing Financial Services. USA : Richard D.Irwin, Inc.

Saad al-harran et al. 1994. Islamic Marketing Strategy Eradacting Rural Poverty in Malaysia. Selangor: Pelanduk Publication.

Sarwono, Jonathan. 2007. Analisis jalur untuk riset bisnis dengan SPSS. Yogyakarta : Penerbit: Andi.

Sekaran, Uma. 2000. Research Methods For Business. USA: John Wiley \& Sons, Inc.

Siamat, Dahlan. 2005. Manajemen Lembaga Keuangan. Edisi Kelima, Jakarta : Fakultas Ekonomi Universitas Indonesia.

Suhendi, Hendi. 2008. Strategi Optimalisasi Peran BMT Sebagai Penggerak Sektor Usaha Mikro, Bandung : Fakultas Syariah dan Hukum UIN SGD.

Warjiyo, Perry. 2004. Mekanisme Transmisi Kebijakan Moneter di Indonesia. Jakarta: Pusat Pendidikan dan Studi Kebanksentralan BI.

Wiyono, Slamet. 2005. Akuntansi Perbankan Syariah. Jakarta : Grasindo.

Zulkifli, Sunarto. 2003. Panduan Praktis Transaksi Perbankan Syariah. Jakarta : Zikrul Hakim. 